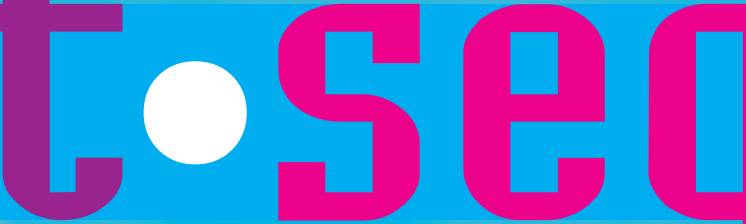

The Low Countries Journal jaargang 17

of Social and Economic 2020

History

nummer 3

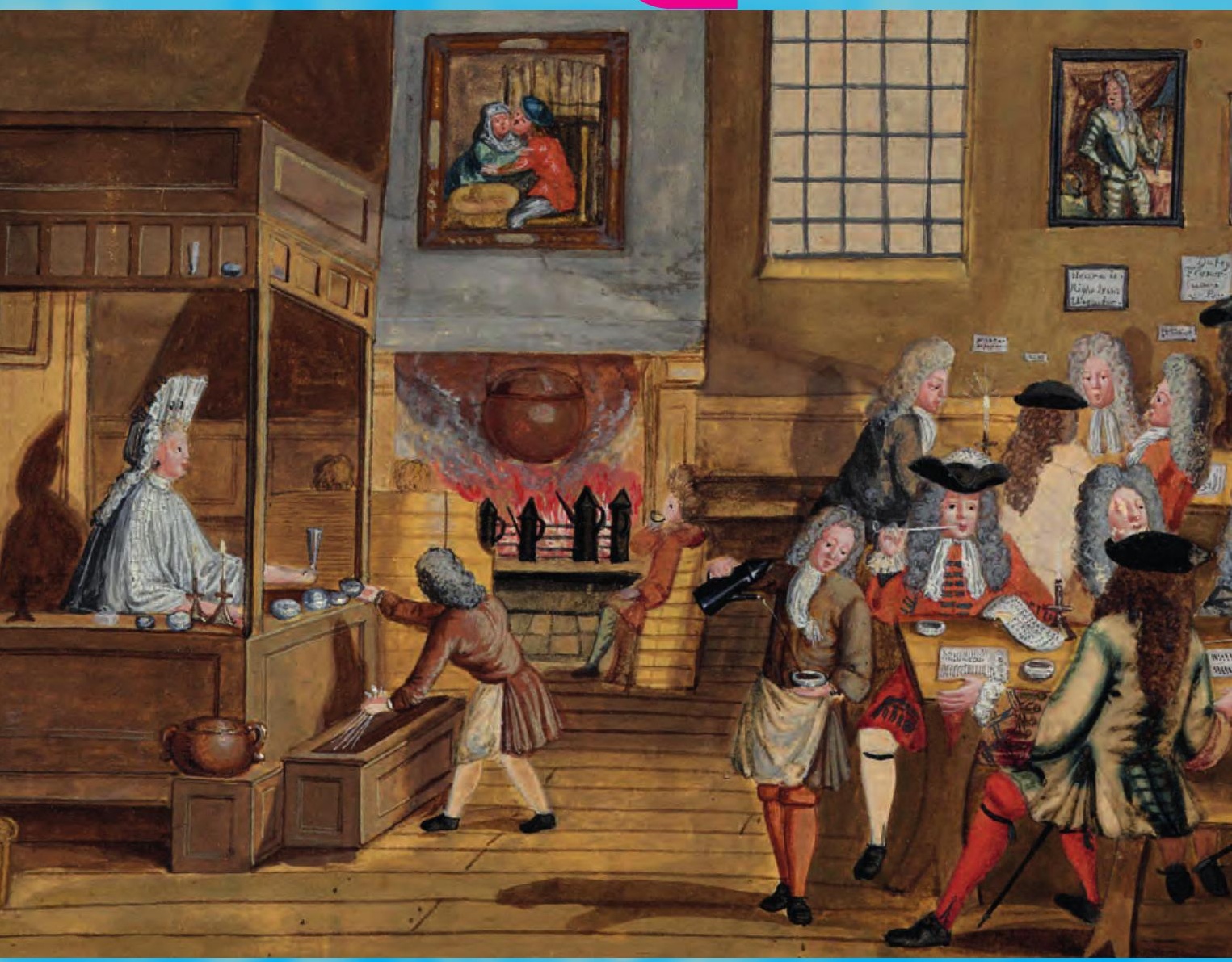

- Newcomers, Migrants, Surgeons [Groot]

- In Vino Veritas [Walschap]

- Dossier Maarten Prak's Citizens without Nations - a Debate

- Boeken over de Tweede Wereldoorlog [Lak] 


\title{
Maarten Prak's Citizens without Nations and the Legal History of Spain
}

\author{
Tamar Herzog \\ TSEG $17(3): 91-100$ \\ DOI: $10.1835^{2} /$ tseg. 1169
}

\begin{abstract}
This text summarizes some of the findings regarding municipal citizenship (vecindad) and membership in the kingdom community (naturaleza) in Spain from the middle ages to the twentieth century and compares and contrasts them with the conclusions reached by Maarten Prak. Basically agreeing with his main discoveries, it nonetheless argues that in Spain, at least, many of the features described by Prak did not disappear in the aftermaths of the French Revolution but instead persisted into the nineteenth and the twentieth century. Furthermore, this text also advocates for the importance of law. It suggests that bringing in the law would have facilitated both the description and the understanding of many of the very interesting phenomena described by the author.
\end{abstract}

In Citizens without Nations, Maarten Prak calls upon us to imagine a world of cities rather than states. Criticizing previous generations for ignoring the importance of urban politics, he suggests that a longer and larger inquiry would remind us of a time, in which local communities auto-regulated themselves and allowed for civic participation through town councils, guilds, urban welfare agencies, and local militia. Despite differences in intensity and chronology, this experience was shared across Europe and elsewhere, in both republican and monarchical territories. Thus, if once-upon-a-time we had assumed that municipal citizenship was somewhat important in the Middle Ages, but that its significance waned with the coming of the Leviathan, in reality, this transition did not take place until the French Revolution. It was only in the aftermaths of the Revolution that a great variety of actors came to imagine citizens as inhabiting states and politics as the territory of national rather than local actors. The Revolution also abolished guilds and guild governance, invented a national welfare system, and nationalized 
the army. According to Prak, these developments marked the demise rather than the intensification of democracy. They also harmed economic performance because it was the involvement of citizens in communal governance that guaranteed economic success.

Prak establishes that citizenship was a wide-spread experience throughout much of the Old Regime. He shows that defacto it was practiced by many non-citizens and enabled popular political participation. He demonstrates that it was a vital institution that could explain important political, economic, and social developments and he clarifies that late medieval and early modern states accounted for, and accommodated, municipal interests. All these conclusions lead Prak to propose that we consider the prospect of another future, in which municipal autonomy and civic involvement will be revived.

Implied in this argument is the need to revise our narratives of state formation by remembering that Old Regime societies featured corporate structures. These structures guaranteed that, rather than concentrated in the hands of a single authority, governance (encompassing administration, legislation, and judicial activity) as well as the corollary participation, was divided among a great variety of actors. By reminding us of these important features, Prak joins a distinguished group of historians who accused their peers of searching for present-day structures where none existed. ${ }^{1}$ Viewing this search as an anachronistic pursuit, these historians concluded that identifying the early modern state with the king or with republican authorities obscured rather than enhanced our understanding of the past. Instead of maintaining the old notion according to which the emergence of states was a process that necessarily involved the subjection of pre-existing corporate bodies, these historians concluded, among other things, that the claim that local identities were progressively replaced by loyalty to a broader community and a superior authority reflected a political project, not a historical reality. It represented nineteenth- and twentieth-century preoccupation with the endurance, rather than waning, of municipal bodies, which contemporary thinkers believed was unwarranted, even harmful.

Prak is right that these lessons have mostly gone unnoticed by social and urban historians, not to mention political scientists. His wish to test these insights in a larger context, while also asking broader questions, is important and timely. It allows not only to ask questions about the past, but also to inquire as to how scholars (and politicians) have sought to

1 P. Costa, Semantica del potere politico nel pubblicistica medievale (1 100-1433)(Milan 1969); B. Clavero, Tantas personas como estados. Por una antropología política de la historia europea (Madrid 1986). 
uncover, but also create, what had transpired. Furthermore, it suggests that, even today, we may still strive to forge another future, in which municipalities rather than states would organize our lives, control our behavior, and elicit our allegiance.

The case of Spain, which I studied in 2003, was emblematic of many of these predicaments. ${ }^{2}$ Despite insistence by both scholars and politicians that the early modern Spanish state was centralized and absolute, I found plenty of indications that such was never the case. Rather than unitary structures, the Iberian kingdoms were made up of local communities, each with its own council, citizen body, and customary legal regime (fuero). ${ }^{3}$ Spanish municipal corporations were charged with implementing most royal policies: they collected taxes, recruited soldiers, and applied royal justice. While constantly representing the king locally, these corporations also zealously protected their autonomy, which they argued reflected an ancient constitution that the king could not modify. ${ }^{4}$ Their members resisted royal pretensions when they considered them inappropriate and refused to collaborate when collaboration was deemed undesirable. Spanish municipal bodies responded to such pretensions individually or in parliament (Cortes), which was an assembly of city representatives. In parliament, Iberian municipal bodies expressed grievances, received concessions, and pressed for reforms. ${ }^{5}$ They discussed, as in the case of Castile, measures to ensure monetary stability, encourage agricultural production, reverse the privatization of common lands, or institute commercial monopolies. ${ }^{6}$ It

2 T. Herzog, Defining nations. Immigrants and citizens in early modern Spain and Spanish America (New Haven 2003). Translations include Vecinosy extranjeros. Hacerse español en la edad moderna (Madrid 2006) and Nations, citoyens, immigrés dans L'Espagne et l'Amérique espagnole du XVIIIe siècle (Paris 2017).

3 H. Nader, Liberty in absolutist Spain. The Habsburg sale of towns 1516-1 700 (Baltimore 1990) 207, referred to this reality by explaining that the most powerful monarchy in the early modern period governed itself through thousands of direct connections to minute municipal corporations.

4 J.A. Pardos Martínez, “Constitución Patricia” y "comunidad" en Burgos a finales del siglo XV (Reflexiones en torno a un documento de 1475)', in: E. Sáez, C. Segura Craíño and M. Cantera Montenegro (eds.), La ciudad hispánica durante los siglos XII al XVI, vol. 1 (Madrid 1987) 545-58o.

5 J.I. Fortea Pérez, Monarquía y cortes en la corona de Castilla: Las ciudades ante la política fiscal de Felipe II (Salamanca 199o); I.A.A. Thompson, Crown and Cortes. Government, institutions and representation in early modern Castile (Aldershot 1993); S. de Dios, 'Corporación y nación. De las cortes de Castilla a las Cortes de España', in: P. Cappellini et al. (eds.), De la ilustración al liberalismo. Symposium en honor al prof. Paolo Grossi (Madrid 1995) 197-298.

6 J. Martínez Cardós, Las Indias y las Cortes de Castilla durante los siglos XVI y XVII (Madrid 1959); D.E. Vassberg, 'The Sale of Tierras Baldías in Sixteenth-Century Castile', The Journal of Modern History 47:4 (1975) 629-654, 633 and 653; and P. Martín Prieto,'Política agraria en las Cortes de Castilla (11881351)', De Medio Aevo 1 (2012) 1-22. 
was there where important questions such as reforming the civil and criminal procedure and determining the hierarchy of legal sources were decided and where discussions confirmed the primacy of local customs (fueros) over royal restatement of Roman Law (Siete Partidas) and royal decisions. From the 153 os, the Castilian Cortes also controlled royal finances and, from 1590, a parliamentary committee oversaw both tax collection and royal spending.

The vitality of Iberian municipal corporations continued throughout the early modern period. It was particularly evident in the early nineteenth century during the Napoleonic invasion of Spain. On that occasion, Spaniards who denied the legitimacy of the French occupying power constituted municipal juntas that were to govern the country. Suggesting that, in the absence of a legitimate ruler, sovereignty returned to the people, contemporary actors concluded that 'the people' were best represented by their traditional agents, the municipal bodies. This move resulted in extreme fragmentation as each municipal junta acted as a sovereign body in both internal and external affairs and refused to collaborate with the other juntas, arguing that such a collaboration would imply the unlawful abdication of its powers.

If the vitality of corporations was clear in Spain, so was the importance of citizenship. During the Old Regime, three factors determined the status, rights, and obligations of all individuals living in Iberia. These included local belonging (local citizenship, identified as vecindad), membership in the kingdom community (naturaleza) and subjecthood (vasallaje). Gradually crystalizing during the late Middle Ages, by the sixteenth century most discussants agreed that while citizenship designated horizontal ties, subjecthood featured vertical ties. While citizenship created relations with the community and entailed the automatic application of a particular regime of rights and obligations, subjecthood designated a personal relationship with the king, who was under the duty to reward loyalty with protection. Though in most cases citizens were vassals and vassals citizens, such was not always the case. Many vassals could and did often remain external to the community despite their personal relationship with the monarch. Their exclusion from citizenship meant that these vassals, who were nonetheless judged foreign, were ineligible to important rights such as the usage of common lands or voting in local elections (citizenship in local communities), the right to hold public office, ecclesiastical benefice, or immigration and trade in the colonies (citizenship in the kingdom community). Judging from the Spanish example, Prak is therefore right that citi- 
zenship was central to the experience of early modern Europeans. He is also right that it was often assumed by performance rather than obtained by formal declarations. In my own work I discovered that both litigants and those who opposed them, both local and royal authorities, both jurists and laymen explained that, rather than being automatically abstracted from birth or descent, citizenship depended on attachment to the community. Attachment could be demonstrated in multiple ways: local residence, marriage to a local person, ownership of real estate, paying taxes, or serving in the militia, to mention just a few emblematic examples. Although a legal presumption protected those born locally to locally born parents - in their case it was assumed that they were attached to the community - if there was reason to believe that such was not the case, then despite local birth to locally born parents, these individuals would be considered aliens. The same was true of those born outside the community to foreign parents. In their case, the presumption held that they had no attachment to the community. But if they could demonstrate that they did (by referring to the indications enumerated above that demonstrated integration) then they would be recognized as members. Because at stake was a status (citizenship), which was generated by behavior (residing, paying taxes, serving in the militia, and so forth), the grant (and expiration) of citizenship did not depend on formal declarations. Formal declarations could help individuals and communities know who was whom and who merited which treatment, but they did not make people citizens. Instead, these declarations only recognized who people already were. As a result, those who behaved as citizens or natives could be considered thus without a formal declaration, their citizenship being introduced, it was argued, by way of performance.

These debates explained how municipal citizenship could maintain its centrality despite the emergence of states. Because integration was always achieved within the contours of a concrete place, where one resided, worked, or payed taxes, de facto, to prove that one was a natural it was vital to demonstrate local citizenship (vecindad). In other words, throughout the early modern period, the presupposition in Spain was that vecinos (citizens of municipal communities) were also by extension naturales (members of the kingdom community). The contrary was also true: those naturales who lost their municipal citizenship ceased having rights in the kingdom. By the seventeenth century, the tying of municipal to kingdom citizenship was so strong that foreigners who obtained local citizenship were automatically naturalized. There- 
after, municipal communities became the main gatekeepers also of the kingdom community because it was their recognition of individuals as citizens that allowed these individuals to integrate also in the kingdom. Rather than replacing local citizenship with a kingdom-wide membership as historians have often assumed, the coming of the early modern state in Spain, at least, elevated local citizenship by making it an essential prerequisite to obtain rights and privileges in what was to become the national community.

My empirical research in Spain thus confirmed much of what Prak argues. It suggested that municipal citizenship was important, even essential, throughout the early modern period and it affirmed that it was through participation in corporate bodies that individuals could insert themselves as citizens, participate in the running of the community, and demand rights while also obeying duties. Yet, despite this important agreement, there are two ways by which my own work diverts from (though not necessarily contradicts) Prak's. One is the question whether these configurations radically changed in the aftermaths of the French Revolution. The other is the importance of law.

In my 2003 work I did not look beyond the early nineteenth century. In 2007 , however, I was invited to reflect on what happened to early modern structures in the nineteenth and twentieth centuries. ${ }^{7} \mathrm{My}$ conclusion was that, despite the changes proposed by the French Revolution, in Spain, at least, national citizenship continued to be tied to municipal adhesion. The new constitutions enacted in the nineteenth century did follow the French Revolution in declaring that the nation was sovereign and in creating national assemblies. However, the nation they imagined was still a composite structure, made of thousands of local communities, and Spaniards were still conceived as members, indeed, citizens of local communities. Other pieces of legislation and the jurisprudence of the courts affirmed the same. ${ }^{8}$ Declaring that the nation was no other than a collection of local citizens, these juridical arrangements left in hands of municipal authorities - not central state organs - the duty (and privilege) to determine who national citizens were. Proof continued to depend not on formal declarations, birth or descent, but on demonstrating a behavior that manifested attachment

7 T. Herzog, 'Communities becoming a nation. Spain and Spanish America in the wake of modernity (and thereafter)', Citizenship Studies 11:2 (2007) 151-172.

8 These convictions found expression in such diverse legislation such as the constitutions of 1812 , 1837,1869 , and 1876 , the code of commerce (1829), the Civil Code project (1834), the law of Civil Registry (1870), and the new Civil Code (1889). 
to the community. It was only in 1954 that, under Franco's dictatorship, a new definition of Spanish citizenship was adopted. This definition removed the power to decide on national citizenship from municipal bodies, as well as transformed integration from a local to a national affair. It was only in the aftermaths of these legal changes, that the ideas proposed by the French Revolution were at last realized.

As for the importance of law, my own research has demonstrated that, like a diving duck, whether you see it or not, law is always there. ${ }^{9}$ Because it frames discussions and give words and actions a certain meaning, looking to the past without understanding how law operates (even when it operates in the background) is like watching a soccer match without knowing why so many adults run after a single ball. ${ }^{10}$

The importance of law to the understanding of the past cannot be overestimated. ${ }^{11}$ In the case under study here, conversation with legal historians would have confirmed, but also solidified, Prak's arguments. Recent scholarship on customary law, for example, would have clarified the nature of the early modern state and would have explained how European territories could transit to statehood without necessarily eliminating the powers and mediation of municipal corporations, as well as the power and mediation of local law. According to this scholarship, from as early as the second century $\mathrm{AD}$ and into the nineteenth century, European actors invoked customary law mainly in order to validate and legitimate a huge plethora of local arrangements precisely because of the contemporaneously omnipresence of an overreaching common legal universe. ${ }^{12}$ This insight could have an important bearing on Prak's argument because it would allow to envision more clearly how multiple corporations and communities could be incorporated into larger polities without losing their autonomy and (relative) independence.

9 I use here the image coined by Goethe when referring to Roman law: Johann Wolfgang von Goethe. Conversations of Goethe with Eckermann and Soret, transl. John Oxenford (London 1875) 389-39o, a conversation that took place on April 6, 1829. Also see T. Herzog, 'Nombres y apellidos: ¿cómo se llamaban las personas en Castilla e Hispanoamérica durante la época moderna?', Jahrbuch für Geschichte von Staat, Wirtschaft und Gesellschaft Lateinamerikas 44 (2007) 1-36; and Frontiers of possession. Spain and Portugal in Europe and the Americas (Cambridge MA 2015), also available as Fronteras de posesión. España y Portugal en Europa y las Américas (Madrid 2018) and Fronteiras da Posse. Portugal e Espanha na Europa e na América (Lisbon 2018).

10 T. Duve, 'Grenzenlose Räume', Rechtsgeschichte/Legal History 23 (2015) 307-308.

11 On these issues see:T. Herzog. A short history of European law. The last two and a half millennia (Cambridge MA 2018).

12 C. Ando, Law, language, and empire in the Roman tradition (Philadelphia 2011) 30-33; E. Conte, 'Consuetudine, coutume, gewohnheit and ius commune. An introduction', Rechtsgeschichte/Legal History 24 (2016) 234-243. 


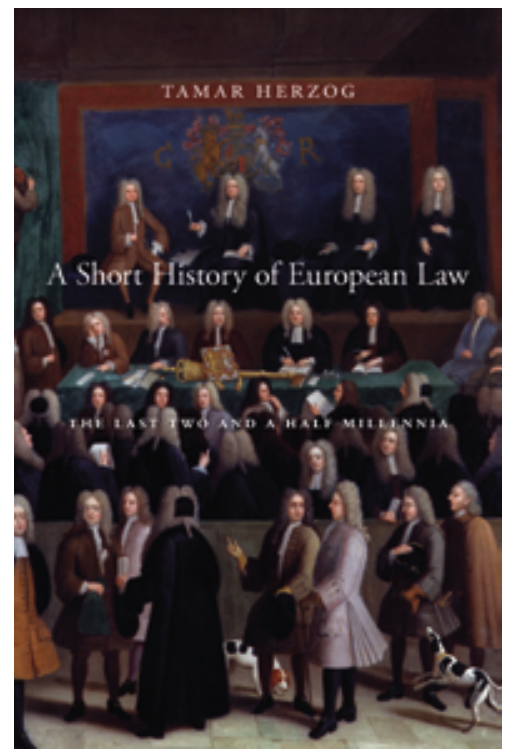

Illustration 1 Cover of Tamar Herzog, A short history of European law. The last two and a half millennia (Cambridge (MA) 2018).

It would suggest that the growing prevalence of customs in the fourteenth and fifteenth centuries was, paradoxically, both a symptom and a consequence of the emergence of states. Rather than manifesting the intensification of local autonomy as historians have once asserted, customs were the building blocks as well as the glue that kept these new polities together. In the fifteenth and the sixteenth century, this enabled many actors to invoke customary law in order to oppose royal or otherwise centralist pretensions. These actors argued that, because local privileges were customary and because they formed part of the pact that allowed the emergence of states, the king (or republican authorities) could not modify them. Thereafter, the main battle ground would no longer be the question whether customs existed (of course they did), but who would be charged with identifying what they mandated. ${ }^{13}$ The example of Zürich, which Prak invokes, was therefore typical of these larger processes. In Zürich as elsewhere, municipal authorities and citizens could insist on maintaining their traditional privileges regardless of the question whether the traditions they invoked were old or recently created.

Legal history could also supply additional cues to some of the other points made by Prak. It could explain the apparent discrepancy between formal citizenship - restricted to a small group - and de facto citizenship, which was widely present. From a legal point of view, citizenship was a status that could be obtained either automatically by act-

13 See, for example, the emblematic case of France, as explored in J.P. Dawson, "The codification of the French customs', Michigan Law Review 38:6 (1940) 765-80o; M. Petitjean, 'La coutume de Bourgogne. Des coutumiers officieux à la coutume officielle', Mémoires de la société pour l'histoire du droit et des institutions des anciens pays bourguignons 32 (1975) 13-20 ; M. Grinberg, 'La rédaction des coutumes et les droits seigneuriaux', Annales HSS 52:5 (1997) 1017-1038. On the invention of customary law also see S. Teuscher, 'Document collections, mobilized regulations, and the making of customary law at the end of the middle ages,' Archival Science 10 (2010) 211-229, and his Lords'rights and peasant stories. The writing and the formation of tradition in the later middle ages, transl. P. Grace, (Philadelphia 2013). 
ing in certain ways, or formally from municipal institutions who, rather than constituting citizens, recognized their pre-existence. Throughout the late medieval and early modern period, municipal authorities often attempted to control who would be eligible to citizenship and thus strove to monopolize status verification. They sometimes succeeded, but this mainly happened when locals found formal proceedings useful because they facilitated interactions that otherwise would demand longer and more complicated procedures or become extremely contentious. In other words, formality was sometimes the prerogative of the authorities but it was often the last resort mainly of individuals who feared opposition and thus wished to acquire a formal certification as to who they were, and which were their rights. Other people were simply happy with acting as citizens and enjoying the rights of citizenship without ever obtaining formal recognition. As a result, it is likely that the more contested citizenship rights and duties were, the more troublesome the local context, the more interest locals would express in obtaining certificates and the more municipal authorities would be able to exercise at least some measure of control over the definition of who citizens were.

If legal history gave no reason to assume that the coming of the Leviathan necessarily harmed local communities or limited their participation, neither did it give reasons to presuppose that the French Revolution had the same effect. After all, the idea of state citizenship had been on the horizon for several centuries, roughly from the fifteenth to the early nineteenth, and during this long-time span its externally manifested unity could easily hide an important sphere of local activity. If such was the case, the question we should ask is not whether national citizenship had emerged in the nineteenth century in detriment of municipal citizenship, or how guilds, welfare organizations and militias fared during this period, but how nineteenth- and twentieth-century actors expressed their grievances, formed their identities, and acted in the political, social, and economic sphere.

\section{About the author}

Tamar Herzog is the Monroe Gutman Professor of Latin American Affairs at Harvard and an affiliated faculty member at the Harvard Law School. She received her PhD at the EHESS in Paris in 1994. She is the author of A Short History of European Law. The Last Two and a Half Millennia (2018, 
available also in Spanish and Mandarin), Frontiers of Possession. Spain and Portugal in Europe and the Americas (2015, available also in Spanish, Portuguese and Brazilian), Upholding Justice. State, Law and the Penal System in Quito (2004, available also in French and Spanish), Defining Nations. Immigrants and Citizens in Early Modern Spain and Spanish America (2003, available also in Spanish and French), Ritos de control, prácticas de negociación (2000, available also in French) and Mediación, archivos y ejercicio (1996). She is the author of over 100 articles and book chapters published in the USA, Canada, UK, Italy, France, Spain, Portugal, Germany, Brazil, Mexico, Colombia, Argentina, Peru, Ecuador, and Israel. https://therzog.fas.harvard.edu/

E-mail: therzog@fas.harvard.edu 


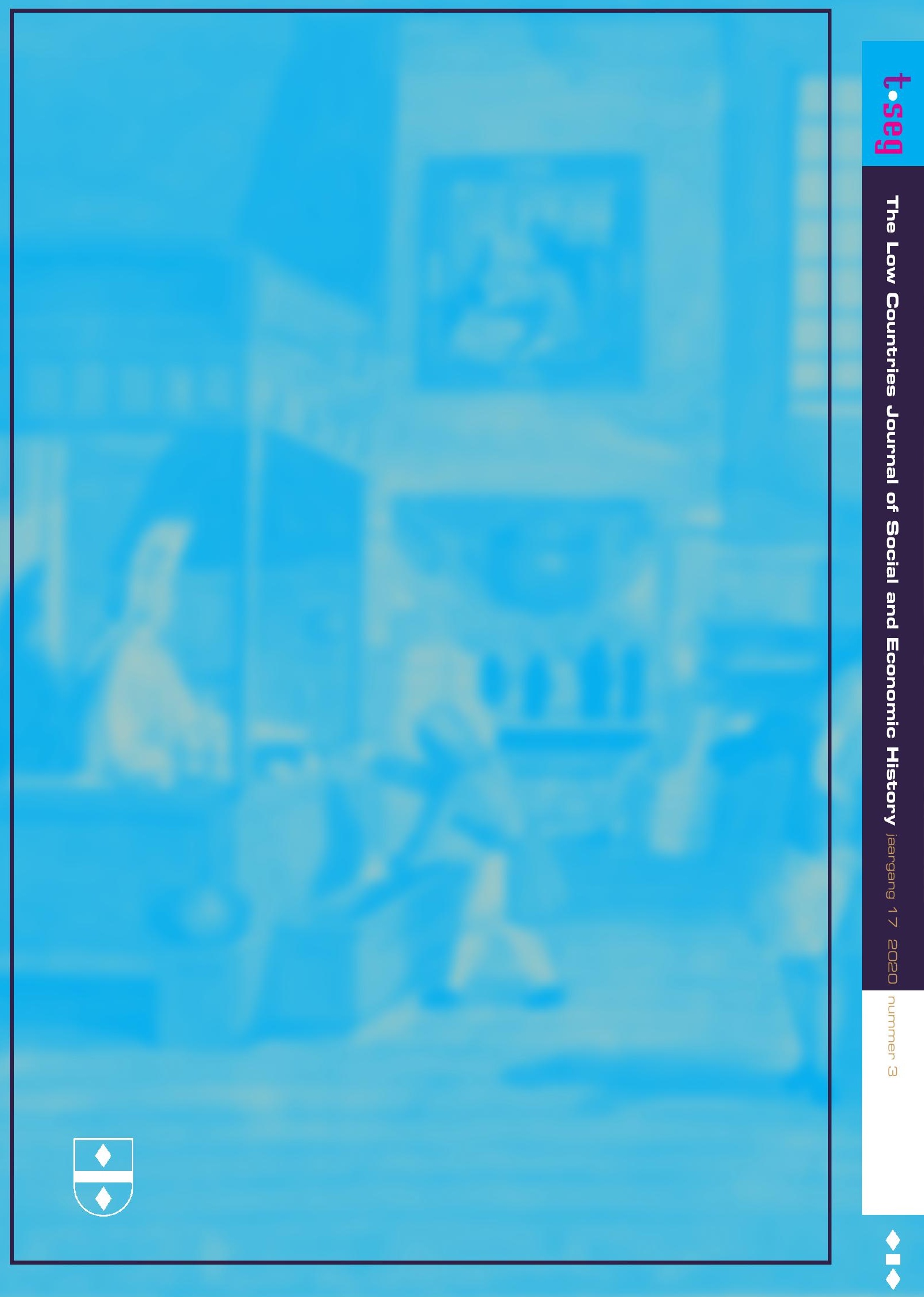

